\title{
National And International Knowledge Transfers When Using Technology On The Conservation \& Restoration Of Paintings
}

\author{
Blanca de-Miguel-Molina, Universitat Politècnica de València, Spain \\ María de-Miguel-Molina, Universitat Politècnica de València, Spain \\ María-del-Val Segarra-Oña, Universitat Politècnica de València, Spain \\ Angel Peiró-Signes, Universitat Politècnica de València, Spain
}

\begin{abstract}
This paper analyses whether there is national and international knowledge transfer in the creative industry of conservation and restoration of paintings. A comparison between American and European museums is exhibited, distinguishing collaboration with research institutes and universities. A bibliometric measurement was used to obtain the data and a factor analysis to examine them. Results show that European and American museums tend to cooperate in knowledge development with other museums, institutes and universities located in its geographical area.
\end{abstract}

Keywords: Knowledge Transfer; Creative Industries; Conservation and Restoration of Paintings

\section{INTRODUCTION: CONSERVATION AND RESTORATION OF PAINTINGS AS A CREATIVE INDUSTRY}

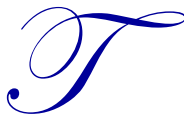

he subsector analysed in this paper, restoring of works of art such as paintings etc., is included in NACE 90 -Creative, arts and entertainment activities- instead of in NACE 91 -Libraries, archives, museums and other cultural activities-. The important thing is that these sectors are creative industries and also knowledge-intensive services (De-Miguel-Molina et al. 2012), and characteristics attributed to KIS sectors make reference to the talent and abilities of persons and firms to create knowledge (Larsen, 2001; Nählinder, 2005; Aslesen and Isaksen, 2007; Doloreux et al., 2008; Strambach, 2008; Muller and Doloreux, 2009; Shearmur and Doloreux, 2009).

The outline that we have used in this paper is as follows: in Sections 2 we briefly summarize the use of bibliometric approach in analysing collaboration between institutions and knowledge transfer. In Section 3, we include the empirical study about collaboration among museum and other institutions; we set out the data extracted from Elsevier's Scopus database, the variables and the methodology used for their study as well as the results obtained. Our conclusions can be found in Section 4.

\section{BIBLIOMETRIC APPROACH TO MEASURE COLLABORATION AND KNOWLEDGE TRANSFER}

Literature about innovation point out, in general, that knowledge and spillovers precede innovation. For this reason, knowledge is considered an input of innovation (Pecquer 1992, Enright 1999, Feldman 2000, Pöyhönen and Smedlund 2004, Power and Lundmark 2004, Cooke et al. 2007). Knowledge is, therefore, a key asset for companies that compete with others and learning is a fundamental process (Maskell and Malmberg 1999). The use of innovation inputs and outputs has been used for some authors to measure innovation (Griliches 1990, Furman et al. 2002, Del Barrio-Castro and García-Quevedo 2005, Moreno et al. 2005, Buesa et al. 2006). Griliches (1990) stressed that the knowledge generated was converted into patents. In the subsector covered in this paper, data for patents would be collected from national surveys if they were available, but it is not the case. One solution is the use 
of bibliometric approach to cover this gap, and especially scientific articles. Different authors have employed scientific articles to study technologies, knowledge and networks (Youtie and Shapira 2008, Leydesdorff and Rafols 2011, Robinson et al. 2011). Abramo et al. (2009) mention that using bibliometric approach to study collaboration between institutions, as universities and industries, through co-authorship of scientific articles also allow determining diffusion of knowledge and skills. And Wall and Boschma (2009) refer to knowledge networks in innovation systems, where diffusion occurs between local agents but also span across the world. In applying a new technology, Boschma (2005) and Rafols et al. (2010) state that actors require cognitive proximity to absorb new knowledge, although too much cognitive proximity may limit innovation.

Literature about knowledge transfer when museums cooperate, in restoration and conservation, with other institutions is scarce. Therefore, the research gap in this paper consists on bring into the open whether exist cooperation among museums and other institutions for using technologies and which are the patterns for these collaborations. Conservation is cited by authors among the main activities in a museum, and essential to preserve its heritage (Papini and Persiani 2004, Kotler et al. 2008). At the end of XVIII siècle and throughout the XIX, art collection and catalogue live with research in physics and chemistry applied to artworks restoration. Museums restoration laboratories and departments were set up during the XIX siècle (Moreira 2008). Therefore, analytical knowledge cooperation coexists in museums since restoration departments were developed. Results confirm that nowadays synthetic knowledge also cooperate with museums.

\section{METHOD AND RESULTS}

Data to measure collaboration and knowledge transfer were scientific co-authored papers. For bibliometric analysis, in the Elsevier's Scopus database were searched, in $27^{\text {th }}$ July 2011, keywords "paint*" AND "restoration" OR "conservation" to obtain publications in international journals about restoration and conservation of painting artworks. The final number of articles was 1,656. These data were imported to VantagePoint software, which was used to: 1) Clean up results for technologies deployed in restoration and conservation, and institutions involved in these processes. Some techniques obtained in the results were: electron microscopy, X-ray diffraction, micro-Raman spectroscopy, lasers and Gas Chromatography-Mass Spectrometry (GC-MS). The number of institutions analysed was 222: 94 museums from 26 countries, 41 conservation and restoration institutes, 49 physics and chemistry universities departments and 38 engineering and Information Technologies universities departments. 2) Elaborate matrixes, based on technologies, for papers co-authorship among museums, restoration institutes and universities. Finally, matrixes were elaborated depending on collaborations in papers: museums with other museums, museums with restorations and conservation institutes, museums with physics and chemistry universities departments, and museums with engineering and Information Technologies universities departments. To quantify collaborations, nine indicators/variables were used and also a geographical approach was defined (Table 1).

Results confirm that $27 \%$ of museums which wrote articles were located in the United States, $10 \%$ in the United Kingdom and 8\% in France. Moreover, the most collaborative museums were located in the US (17.7\%) and UK (9.4), regions where museums were also the most collaborative with national (17.7\% of US museums, $6.3 \%$ of UK museums) and abroad (11.5\% US, and 7.3\% UK). Factor analysis (Principal Component Analysis) and cluster k-means statistics methods were used to analyse data. On the basis of the data input into SPSS program, the principal components (Table 1) were obtained. In the analysis of the relationships between variables, two factors explained 58.5\% of the variance. Values for KMO and Bartlett were 0,743 (KMO) and 0,000 Sig. The two components in rotated matrix show what is confirmed in cluster results, that is, the variables which establish boundaries between clusters 2 and 3 is "Museum cooperated with synthetic university departments (engineering and IT) located abroad". 
Table 1. Matrix of rotated components

\begin{tabular}{|c|c|c|}
\hline Variables & Comp & onents \\
\hline Museum did not cooperate & .911 & \\
\hline Museum cooperated with other museums located in its own country & & .742 \\
\hline Museum cooperated with other museums located abroad & .595 & \\
\hline Museum cooperated with research institutes located in its own country & .660 & \\
\hline Museum cooperated with research institutes located abroad & .791 & \\
\hline Museum cooperated with analytical university departments (physics and chemistry) located in its own country & .673 & \\
\hline Museum cooperated with analytical university departments (physics and chemistry) located abroad & .733 & \\
\hline Museum cooperated with synthetic university departments (engineering and IT) located in its own country & .694 & \\
\hline Museum cooperated with synthetic university departments (engineering and IT) located abroad & & -.649 \\
\hline
\end{tabular}

Principal Components Analysis and Varimax Rotation with Kaiser. Source: Compiled by authors from Scopus database results

The cluster k-means technique was conducted, through the factor scores obtained in factor analysis, in order to obtain group structures. In our opinion, it seemed more suitable to choose three groups to show all the diversity within the museums. ANOVA analysis was used to prove its significance. In addition, the ANOVA analysis applied to each variable used to obtain the groups revealed that all variables discriminate the classification into the three groups with all of them being significant at $\mathrm{p}<0.01$. Three cases can be verified in the clusters depending on whether or not museums cooperated, and the importance of all types of cooperation (Table 2). The first cluster includes museums we call high-collaborative museums, the second are the medium-collaborative museums, and the third are the low-collaborative museums. High-collaborative museums have a higher mean of cooperation in all variables than medium and low collaborative museums, except for cooperation with synthetic university departments (engineering and IT) located in its own country and cooperation with synthetic university departments (engineering and IT) located abroad. This variable brings out the existence of two components in factor analysis and the boundary between clusters 2 and 3. Examples of high-collaborative and medium-collaborative museums are included in table 3.

Table 2. Clusters depending on cooperation

\begin{tabular}{|c|c|c|c|}
\hline \multirow{2}{*}{ Variables } & \multicolumn{3}{|c|}{ Mean } \\
\hline & C1 & $\mathrm{C2}$ & $\mathbf{C 3}$ \\
\hline Museum did not cooperate & 1.39 & 4.12 & 12.83 \\
\hline Museum cooperated with other museums located in its own country & 0.38 & 0.25 & 5.67 \\
\hline Museum cooperated with other museums located abroad & 0.29 & 0.12 & 2.00 \\
\hline Museum cooperated with research institutes located in its own country & 0.34 & 0.75 & 2.33 \\
\hline Museum cooperated with research institutes located abroad & 0.14 & 1.38 & 3.00 \\
\hline Museum cooperated with analytical* university departments located in its own country & 0.14 & 0.38 & 1.83 \\
\hline Museum cooperated with analytical* university departments located abroad & 0.28 & 1.00 & 2.33 \\
\hline Museum cooperated with synthetic ${ }^{* *}$ university departments located in its own country & 0.14 & 1.50 & 1.50 \\
\hline Museum cooperated with synthetic $* *$ university departments located abroad & 0.05 & 2.50 & 0.33 \\
\hline Number of museums & 80 & 8 & 6 \\
\hline
\end{tabular}

* physics and chemistry; ** engineering and IT. Source: Compiled by authors from Elsevier's Scopus database results

It is remarkable that in the high-collaborative group figure important American museums (Metropolitan, Fine Arts in Boston and National Gallery in Washington DC) and The Tate, while in the medium-collaborative group appear important European museums (National Gallery London, Victoria and Albert Museum and Rijksmuseum). Low-collaborative museums are British Museum, State Hermitage Museum and Field Museum Chicago. 
Table 3. Number of cases in each cluster

\begin{tabular}{|c|c|c|c|}
\hline \multirow{2}{*}{ Clusters } & \multicolumn{3}{|c|}{ Examples of museums, located in } \\
\hline & USA & Europe & Other countries \\
\hline $\begin{array}{l}1 \text { - Low } \\
\text { collaborative } \\
\text { museums }\end{array}$ & 20 & 45 & 15 \\
\hline $\begin{array}{l}2 \text { - Medium } \\
\text { collaborative } \\
\text { museums }\end{array}$ & Winterthur Museum, Delaware & $\begin{array}{ll}\checkmark & \text { Kröller-Müller Museum, } \\
& \text { Netherlands; } \\
\checkmark & \text { Museum of Fine Arts, Budapest; } \\
\checkmark & \text { National Gallery, Athens; } \\
\checkmark & \text { National Gallery, London; } \\
\checkmark & \text { Rijksmuseum, Netherlands; } \\
\checkmark & \text { Van Gogh Museum, Netherlands; } \\
\checkmark & \text { Victoria and Albert Museum, } \\
& \text { London }\end{array}$ & 0 \\
\hline $\begin{array}{l}3 \text { - High } \\
\text { collaborative } \\
\text { museums }\end{array}$ & $\begin{array}{ll}\checkmark & \text { Art Institute of Chicago; } \\
\checkmark & \text { Harvard University Art Museums; } \\
\checkmark & \text { Metropolitan Museum of Art, New York; } \\
\checkmark & \text { Museum of Fine Arts, Boston; } \\
\checkmark & \text { National Gallery of Art, Washington, DC }\end{array}$ & Tate Britain, London & 0 \\
\hline
\end{tabular}

Source: Compiled by authors from Elsevier's Scopus database results

\section{CONCLUSIONS}

Restoring of works of art such as paintings, as creative and knowledge-intensive services, is characterized for the creation of knowledge. However, determining this knowledge is difficult due to lack of data from national statistics at a disaggregated level. In other sector with the same problems authors have employed scientific articles, so this is what we attend in this paper. There are not studies about knowledge cooperation and networks in conservation and restoration artworks and about geography of this cooperation, so this paper covers this gap. Results from the cluster analysis show a pattern in cooperation among museums, restoration institutes and universities. Three clusters are found: high-collaborative museums, medium-collaborative museums, and low-collaborative museums. The first cluster includes museums with a higher mean of cooperation in all variables than medium and low collaborative museums, except for cooperation with synthetic university departments (engineering and IT) located in its own country and cooperation with synthetic university departments (engineering and IT) located abroad. In the high-collaborative group figure important American museums while in the medium-collaborative group appear important European museums.

\section{ACKNOWLEDGMENTS}

The authors would like to thank Ministry of Science and Innovation for financially supporting this research (ECO2010-17318 MICINN Project) and Search Technology Inc for a trial version 7.0 of the VantagePoint Software.

\section{AUTHOR INFORMATION}

Blanca de-Miguel-Molina, Ph.D. in Management and Business Administration (Universitat Politècnica de València). Associate Professor at Industrial Engineering School (Universitat Politècnica de València). E-mail: bdemigu@omp.upv.es

María de-Miguel-Molina, Ph.D. in Management and Business Administration (Universitat Politècnica de València). Associate Professor at Faculty of Management and Business Administration (Universitat Politècnica de València).E-mail: mademi@omp.upv.es

Maria-del-Val Segarra-Oña, Ph.D. in Management and Degree in Industrial Engineering. Associate Professor in Innovation and Competitiveness at the School of Industrial Engineering at the Universidad Politécnica, Valencia (Spain). E-mail: maseo@omp.upv.es (Corresponding author) 
Angel Peiró-Signes, Ph.D. in Business Administration and Degree in Industrial Engineering. Assistant Professor in Analytical Accounting in Manufacturing firms and Strategic Management at the Universidad Politécnica de Valencia (Spain). E-mail: anpeisig@omp.upv.es

\section{REFERENCES}

1. Abramo G, D’Angelo CA, DiCosta F, Solazzi M (2009) University-industry collaboration in Italy: A bibliometric examination. Technovation, 29. 6/7: 498-507.

2. Aslesen HW and Isaksen A (2007) Knowledge intensive business services and urban industrial development. The Service Industries Journal, 27.3: 321-338.

3. Boschma RA (2005) Proximity and Innovation: A Critical Assessment. Regional Studies, 39.1:61-74.

4. Buesa M, Heijs J, Martínez Pellitero M and Baumert T (2006) Regional systems of innovation and the knowledge production function The Spanish case. Technovation, 26.4: 463-472.

5. Cooke P and de Laurentis C, Tödtling F and Trippl M (2007) Regional Knowledge Economies: Markets, Clusters and Innovation, Great Britain: Edward Elgar Publishing.

6. Courlet C and Pecquer B (1992) Les systèmes industriels localisés en France: Un nouveaux modèle de développement, in: G Benko and A Lipietz (Eds) Les régions qui gagnent. Districts et réseaux : Les nouveaux paradigmes de la géographie industrielle, p. 81-102, Paris: P.U.F.

7. Del Barrio-Castro T and García-Quevedo J (2005) Effects of university research on the geography of innovation. Regional Studies, 39.9: 1217-1229.

8. De-Miguel-Molina B, Hervas-Oliver JL, Boix R and De-Miguel-Molina M (2012): The Importance of Creative Industry Agglomerations in Explaining the Wealth of European Regions. European Planning Studies, 20.8: 1-18.

9. Doloreux D, Amara N and Landry R (2008) Mapping regional and sectoral characteristics of knowledgeintensive business services: Evidence from the province of Quebec (Canada). Growth and Change, 39.3: 464-496.

10. Enright MJ (1999) Regional clusters and firm strategy, in: AD Chandler, P Hagström and Ö Sölvell (Eds) The Dynamic Firm. The Role of Technology, Strategy, Organization and Regions, p. 315-342, Great Britain: Oxford University Press.

11. Feldman P F (2000) Location and innovation: The new economic geography of innovation, spillovers, and agglomeration, in: G Clark, M Feldman and M Gertler (Eds) The Oxford Handbook of Economic Geography, p. 373-394, Oxford: Oxford University Press.

12. Furman J L, Porter M E and Stern S (2002) The determinants of national innovative capacity. Research Policy, 31.6: 899-933.

13. Griliches Z (1990) Patent statistics as economic indicators: A survey, Journal of Economic Literature, XXVIII: 1661-1707.

14. Kotler NG, Kotler P and Kotler WI (2008) Museum Marketing \& Strategy. $2^{\mathrm{a}}$ Ed. Jossey-Bass. Wiley. USA.

15. Larsen J N (2001) Knowledge, human resources and social practice: The knowledge-intensive business service firm as a distributed knowledge system. The Service Industries Journal, 21.1: 81-102.

16. Leydesdorff L and Rafols I (2011) Local Emergence and Global Diffusion of Research Technologies: An Exploration of Patterns of Network Formation. Journal of the American Society for Information Science and Technology, 62.5:846-860.

17. Maskell P and Malmberg A (1999) Localised learning and industrial competitiveness. Cambridge Journal of Economics, 23.2: 167-185.

18. Moreira Teixeira JC (2008) La teoría en la práctica de la conservación / restauración del arte contemporáneo. $9^{\mathrm{a}}$ Jornada de Conservación de Arte Contemporáneo. Museo Nacional Centro de Arte Reina Sofía. Madrid, p. 209-218.

19. Moreno R, Paci R and Usai S (2005) Spatial spillovers and innovation activity in European regions. Environment and Planning A, 37.10: 1793-1812.

20. Muller E and Doloreux D (2009) What we should know about knowledge-intensive business services, Technology in Society, 31.1: 64-72.

21. Nählinder J (2005) Innovation and Employment in Services. The Case of Knowledge Business Services in Sweden, Sweden: Unitryck Linko" ping. 
22. Papini F and Persiani N (2004) The enhancement of art assets through the establishment of foundations: the case of the Marino Marini foundation in Florence. In Lazzeretti L (ed.) Art Cities, Cultural Districts and Museums. Firenze University Press. Italia. Chap. 7, p. 139-161.

23. Power D and Lundmark M (2004) Working through knowledge pools: Labour market dynamics, the transference of knowledge and ideas, and industrial clusters. Urban Studies, 41.5/6: 1025-1044.

24. Pöyhönen, A. \& Smedlund, A (2004) Assessing intellectual capital creation in regional clusters. Journal of Intellectual Capital, 5.3: 351-365.

25. Rafols I, Porter A and Leydesdorff L (2010) Science Overlay Maps: A NewTool for Research Policy and Library Management. Journal of the American Society for Information Science and Technology, 61.9:1871-1887.

26. Robinson DKR, Huang L, Guo Y, Porter AL (2011) Forecasting Innovation Pathways (FIP) for new and emerging science and technologies. Technological Forecasting \& Social Change, in press.

27. Shearmur R and Doloreux D (2009) Place, space and distance: Towards a geography of knowledgeintensive business services innovation. Industry and Innovation, 16.1: 79-102.

28. Strambach, S. (2008) Knowledge-intensive business services (KIBS) as drivers of multilevel knowledge dynamics. International Journal of Services Technology and Management: 10.2/3/4: 152-174.

29. Wall A and Boschma RA (2009) Applying social network analysis in economic geography: framing some key analytic issues. The Annals of Regional Science, 43.3:739-756

30. Youtie J and Shapira P (2008) Mapping the nanotechnology enterprise: a multi-indicator analysis of emerging nanodistricts in the US South. Journal of Technology Transfer, 33.2:209-223 